\title{
Current Research: Recent Documentation of Ceramic Vessels and Other Funerary Objects in the Titus Phase Cemetery at the Tuck Carpenter Site, Camp County, Texas
}

\author{
Timothy K. Perttula \\ Heritage Research Center, Stephen F. Austin State University \\ Mark Walters \\ Heritage Research Center, Stephen F. Austin State University \\ Kevin Stingley \\ Texas Archeological Stewardship Network, Texas Historical Commission \\ Tom Middlebrook
}

Follow this and additional works at: https://scholarworks.sfasu.edu/ita

Part of the American Material Culture Commons, Archaeological Anthropology Commons, Environmental Studies Commons, Other American Studies Commons, Other Arts and Humanities Commons, Other History of Art, Architecture, and Archaeology Commons, and the United States History Commons

Tell us how this article helped you.

This Article is brought to you for free and open access by the Center for Regional Heritage Research at SFA ScholarWorks. It has been accepted for inclusion in Index of Texas Archaeology: Open Access Gray Literature from the Lone Star State by an authorized editor of SFA ScholarWorks. For more information, please contact cdsscholarworks@sfasu.edu. 
Current Research: Recent Documentation of Ceramic Vessels and Other Funerary Objects in the Titus Phase Cemetery at the Tuck Carpenter Site, Camp County, Texas

Creative Commons License

(c) (1) (9)

This work is licensed under a Creative Commons Attribution-NonCommercial 4.0 International License 


\title{
Current Research:
}

\section{Recent Documentation of Ceramic Vessels and Other Funerary Objects in the Titus Phase Cemetery at the Tuck Carpenter Site, Camp County, Texas}

\author{
Timothy K. Perttula ${ }^{1}$, Mark Walters ${ }^{1}$, Kevin Stingley ${ }^{2}$, and Tom Middlebrook ${ }^{2}$ \\ ${ }^{1}$ Environmental and Archaeological Consultants, LLC. \\ ${ }^{2}$ Texas Archeological Society
}

Recently, we had the opportunity to complete the documentation of Late Caddo period Titus phase ceramic vessels and other funerary offerings from the Tuck Carpenter site (41CP5) in the Big Cypress Creek basin in Camp County, Texas (Figure 1). This portion of the funerary assemblage from the site has been in the hands of R. W. Walsh since the 1960s. Unable to properly care for the assemblage, he recently donated his collection to an anonymous individual, who graciously allowed us to fully document these funerary offerings.

The Tuck Carpenter site (41CP5), on Dry Creek several miles from its confluence with Big Cypress Creek (see Figure 1), is perhaps the best known Titus phase cemetery in the Big Cypress Creek basin in East Texas. This is due to the careful analysis and reporting of the recovered funerary offerings and remains from 45 burials excavated by Robert L. Turner and R. W. Walsh between 1963-1967 (Turner 1978, 1992). More than 95 percent of the graves had the bodies of single individuals laid in an extended supine position on the floor of the pit, but two burial features (Burials 21 and 23) had two individuals placed side by side in the burial pit.

The Tuck Carpenter site is a large community cemetery that was apparently used for the interment of Caddo peoples for a considerable span of time in the fifteenth to the seventeenth century A.D. The burials were laid out in an east-west direction in a number of rows (Turner 1978:Figure 3) (Figure 2), amidst an existing midden deposit. A wide assortment of funerary offerings were placed in the graves, including 402 ceramic vessels, eight ceramic pipes, four ceramic ear spools, two wood ear ornaments, one sandstone ear spool with a copper plate covering, one sandstone ear spool, 57 Talco arrow points, 19 Maud points, 55 Bassett points, 57 Perdiz point, one arrow point of unidentified type, one large chipped biface or Galt biface
(Thurmond 1990:Table 23) of non-local Central Texas chert (Thurmond 1990:144), one biface fragment, seven celts, one metate, four manos, four abrading stones, two polishing stones, one chipped gouge, deer mandibles, deer beamers, clay pigment masses, one marine shell columella bead, turtle carapaces, and mussel shells (Turner 1978:12-49). Perttula et al. (2010) documented 200 ceramic vessels from the Turner collection from the Tuck Carpenter site, along with four ceramic elbow pipes, while Perttula et al. (2014) documented another 14 vessels in the Turner collection; the provenience of two of these vessels is not known.

There are another 65 ceramic vessels in the Margaret Hinton collection from the Tuck Carpenter site (Perttula et al. 2012). The provenience of these vessels in burial features is unknown, but they were likely obtained from looted burials obtained by unknown individuals. Such looted burials were plotted by Turner (1992:Figure 2) as being in the northern and eastern parts of the cemetery.

The Walsh collection from the Tuck Carpenter site includes 175 ceramic vessels, three ceramic elbow pipes, 45 arrow points of the Perdiz, Bassett, Maud, and Talco types, one large Galt biface made from a Central Texas chert, a single petaloid celt of Ouachita Mountains greenstone, four deer bone beamers (see Turner 1978:Figure 10b-e), and 29 unmodified mussel shell valves from two burial features.

Including the Walsh collection with other known collections from the Tuck Carpenter site, a total of 452 ceramic vessels have now been documented from at least 45-50 burial features at the site (see Turner 1978, 1992). These vessels include utility wares (26.8 percent of the vessel assemblage), fine wares (67.5 percent), and plain wares (5.8 percent); more than 98 percent of the vessels are tempered with grog. Among the different 


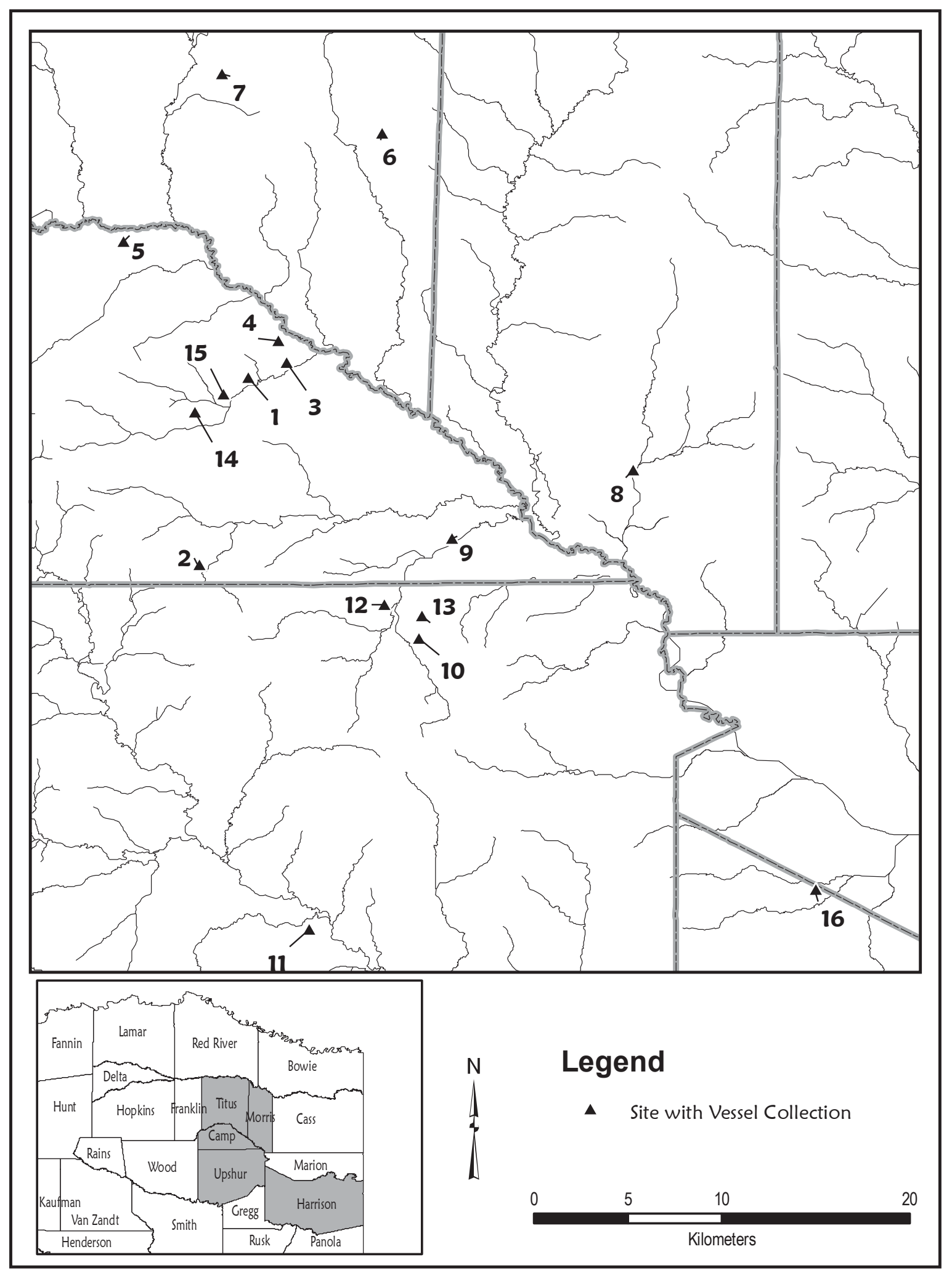

Figure 1. Location of sites with documented vessel collections in the Big Cypress Creek basin in East Texas, including the Tuck Carpenter site: 1, Tuck Carpenter; 2, Johns; 3, Harold Williams; 4, Guest; 5, Horton; 6, Alex Justiss; 7, Keith; 8, Lone Star Lake; 9, Rumsey; 10, Keeling; 11, Moughon; 12, Graydon Adkins \#1; 13, Graydon Adkins \#2; 14, Lineburger;15, Pug Wilson; and 16, Patton. 


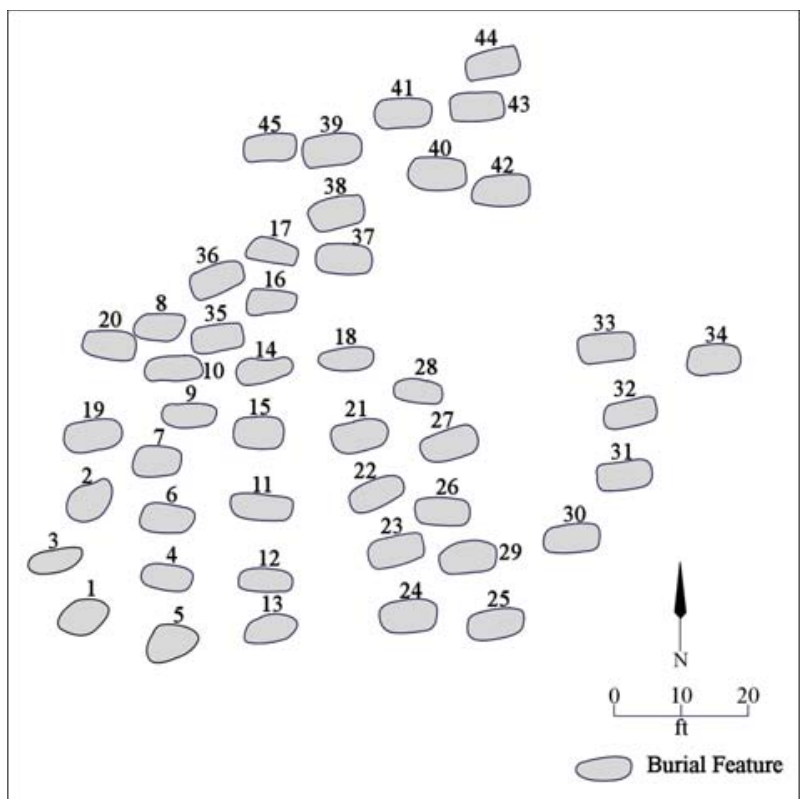

Figure 2. Plan of the cemetery at the Tuck Carpenter site.

wares and identified decorated types, the most common utility wares are Harleton Appliqued, Mockingbird Punctated, Maydelle Incised, and Bullard Brushed jars. The most common fine wares are Ripley Engraved, var. Carpenter and Ripley Engraved, var. Galt, but also present in burial features are other Ripley Engraved varieties, Avery Engraved, Hood Engraved, Johns Engraved, Simms Engraved, Turner Engraved, and Wilder Engraved vessels. These are carinated bowls, compound bowls, bottles, bowls, effigy bowls, jars, and ollas. Red or white pigments were rubbed in the engraved lines on 48 percent of the fine ware vessels.

The most distinctive of the vessels in the Walsh collection is an engraved effigy bowl from Burial 27. It is a large effigy bowl that represents an abstract human head and body, with a broad tab tail (Figure 3 ). The hollow effigy head has an appliqued nose (32 $\mathrm{mm}$ in length and $17.5 \mathrm{~mm}$ in width) and two small openings at the base of the node. To the sides and below the nose are two circular appliqued nodes (16-18 $\mathrm{mm}$ in diameter).

The opening of the bowl sits on the body mid-section, and there is a single circular engraved line around the opening; there are small (4.1-5.0 mm in diameter) suspension holes above and below the opening. On either side of the body are three sets of cross-hatched engraved diamond elements with a red pigment rubbed in the engraved lines. The broad rectangular tail or platform below the bowl opening has

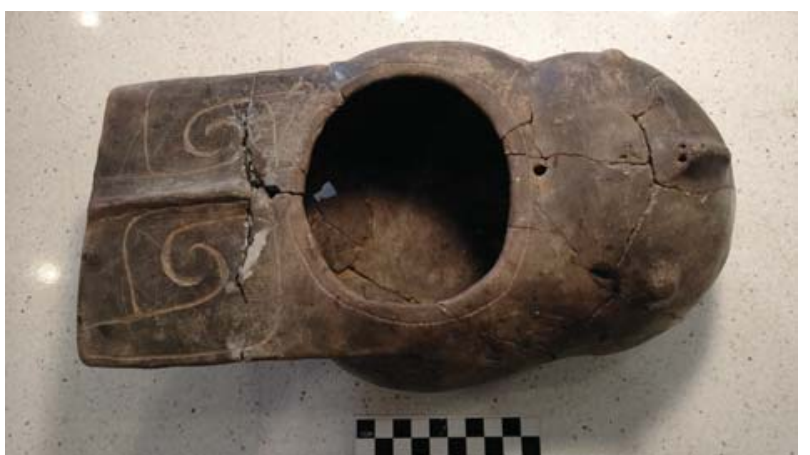

Figure 3. Effigy bowl (Burial 27, Pot 14) from the Tuck Carpenter site.

a central appliqued ridge (see Figure 3) and two sets of engraved hook arm elements that do not meet, such as are seen on Wilder Engraved vessels.

The distribution and co-association of specific ceramic types and varieties with specific arrow point types indicate that burial features with Perdiz arrow points date early in the Titus phase use of the Tuck Carpenter cemetery, followed by burial features with either Bassett or Bassett/Maud points, and then last by Talco arrow points. Bounding the temporal interval of the different cemetery episodes of use suggests the following: (1) the earliest burial features, with Perdiz points and a variety of ceramic vessel types, likely date from ca. A.D. 1430-1500 (Perttula 2012:374); (2) the burial features with Bassett points date after ca. A.D. 1500 (see Kelley 2012:411), and those with Bassett and Maud points likely date from ca. A.D. 1500 to ca. A.D. 1600, or thereabouts; and (3) the burial features with Talco arrow points likely date after ca. A.D. 1600, and may date as late as ca. A.D. 1680. There is a single radiocarbon date from the Tuck Carpenter site: A.D. $1590+60$ from charred logs in Burial 10 (Turner 1978:98). Burial 10 is one of Turner's Late Component burials, generally associated with Talco arrow points and Ripley Engraved, var. McKinney vessels. The Late Component burials - those with Talco arrow points and Ripley Engraved, var. McKinney vessels - are clustered only along the eastern and western margins of the cemetery (Figure 4), suggesting they were the youngest burial features in the cemetery.

The majority of the burial features, in the core of the cemetery at Tuck Carpenter, may date from as early as ca. A.D. 1430 to around ca. A.D. 1600. The latest burials at the margins of the cemetery (see Figure 


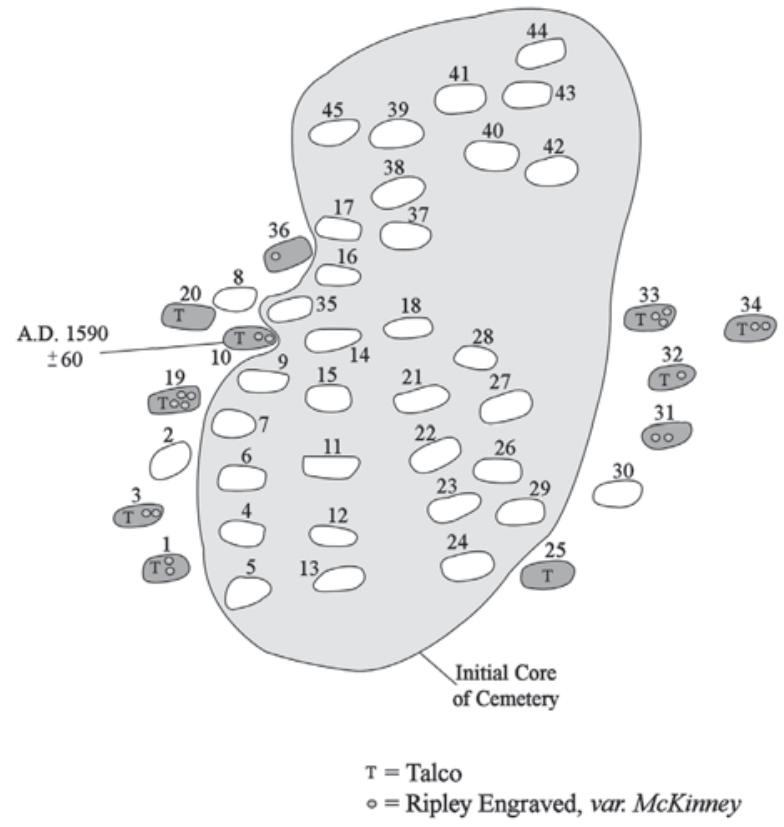

Figure 4. The core area of the Tuck Carpenter cemetery and the location of Late Component graves along its margins.

4) may date to a generation of use between ca. A.D. 1600-1680, and have Talco arrow points and Ripley Engraved, var. McKinney vessels. The Group 4 and 5 elite or high status burials identified by Fields et al. (2014:Table 7.13) from the Tuck Carpenter site (Burials $2,19,23,27,31$, and 40) all occur in the core of the cemetery in burial features primarily dating after ca. A.D. 1500 , but none date clearly too much of the 17 th century. Burial 40 is estimated to date from ca. A.D. 1430-1500 because of its Perdiz arrow point funerary offerings.

\section{References Cited}

Fields, Ross C., Virginia L. Hatfield, Damon Burden, Eloise F. Gadus, M. C. Wilder, and Karl W. Kibler

2014 Testing and Data Recovery Excavations at 11 Native American Archeological Sites along the U.S. Highway 271 Mount Pleasant Relief Route, Titus County, Texas. 2 Vols. Reports of Investigations No. 168. Prewitt and Associates, Inc., Austin.

Perttula, Timothy K.

2012 The Character of Fifteenth- to SeventeenthCentury Caddo Communities in the Big
Cypress Creek Basin of Northeast Texas. In The Archaeology of the Caddo, edited by T. K. Perttula and C. P. Walker, pp. 363-410. University of Nebraska Press, Lincoln and London.

Perttula, Timothy K., P. Shawn Marceaux, and Bo Nelson

2012 Study of the Margaret Hinton Collection of Pottery Vessels from Northeast Texas Caddo Cemeteries. Archeological \& Environmental Consultants, LLC, Austin and Pittsburg.

Perttula, Timonty K., Robert. Z. Selden Jr., and Mark Walters

2014 Documentation of Caddo Vessels in the Robert L. Turner Collection at Stephen F. Austin State University. Special Publication No. 36. Friends of Northeast Texas Archaeology, Austin and Pittsburg.

Perttula, Timothy K., Mark Walters, and Bo Nelson 2010 Caddo Pottery Vessels and Pipes from Sites in the Big Cypress, Sulphur, Neches-Angelina, and Middle Sabine River Basins in the Turner and Johns Collections, Camp, Cass, Cherokee, Harrison, Morris, Titus, and Upshur Counties, Texas and Sabine Parish, Louisiana. Special Publication No. 10. Friends of Northeast Texas Archaeology, Austin and Pittsburg.

Thurmond, J. Peter

1990 Archeology of the Cypress Creek Drainage Basin, Northeastern Texas and Northwestern Louisiana. Studies in Archeology 5. Texas Archeological Research Laboratory, The University of Texas at Austin.

Turner, Robert L., Jr.

1978 The Tuck Carpenter Site and Its Relation to Other Sites Within the Titus Focus. Bulletin of the Texas Archeological Society 49:1-110.

1992 Prehistoric Mortuary Remains at the Tuck Carpenter Site, Camp County, Texas. Studies in Archeology No. 10. Texas Archeological Research Laboratory, The University of Texas at Austin. 